Bangladesh J. Plant Taxon. 25(1): 71-78, 2018 (June)

(C) 2018 Bangladesh Association of Plant Taxonomists

\title{
MORPHOLOGICAL AND ANATOMICAL STUDIES OF THE NEWLY RECORDED RHUS CHINENSIS MILL. (ANACARDIACEAE) FROM TURKEY
}

\author{
ÖZgür Eminagaoglu ${ }^{1}$ AND Melahat OzCan \\ Department of Forest Engineering, Faculty of Forestry, Artvin Coruh University, \\ 08000 Artvin, Turkey
}

Keywords: Rhus chinensis; Anatomy; Chromosome number; SEM; New records; Turkey.

\begin{abstract}
Rhus chinensis Mill. (Anacardiaceae) has been reported as a new record for the flora of Turkey. Detailed morphological description and leaf anatomical properties are provided. Capitate glandular and nonglandular trichomes, and also epicuticle hairs have been observed in the leaf surfaces of $R$. chinensis. Fruit micromorphology and chromosome number of this species have also been evaluated.
\end{abstract}

\section{Introduction}

Anacardiaceae Lindl., the Cashew family, includes more than 700 species in the world belonging to 82 genera that are primarily distributed pantropically. The genus Rhus L., the sumac genus (Spondiadoideae, Rhoeae), is one of the most widespread and recognizable genera in the north temperate zone, includes approximately 250 species from subtropical and warm temperate regions of the world. The genus is divided into two subgenera: Rhus L. and Lobadium (Raf.) Torr. \& A.Gray (Barkley, 1937; Yi et al., 2007).

During field survey in Artvin Province (Turkey), some interesting specimens belonging to Anacardiaceae were collected. After critical study and consultation with relevant literature (Davis et al., 1967; Linchevskii, 1974; Davis, 1988; Güner et al., 2000; Hsu and Su, 2013; Eminağaoğlu, 2015), these specimens were identified as Rhus chinensis Mill. The species was not reported earlier from Turkey (Eminağaoğlu and Anşin, 2003; Eminağaoğlu and Anşin, 2004; Eminağaoğlu et al., 2008; Özhatay et al., 2011; Eminağaoğlu and Ozcan, 2013, 2014; Yuksel and Eminağaoğlu, 2017). The number of species of Rhus in the flora of Turkey is increased to 2 with the addition of this species. In this study, we describe detailed morphological characters of Rhus chinensis, and investigate the anatomical and cytological properties of the species.

\section{Material and Methods}

Morphological analysis

Plant materials were collected from different parts of Artvin, Turkey, at different altitudes between 2013 and 2017. The collected materials were critically studied. The voucher specimens have been deposited at the Herbarium of Artvin Coruh University (ARTH), Artvin, Turkey.

\section{Anatomical preparation}

For anatomical investigation leaf samples were stored in $70 \%$ alcohol. Transverse sections of leaf, and paradermal sections of upper and lower epidermis of leaves were prepared manually using commercial razor blades and stained in Haematoxylin for about 15 min. To remove the excess stain, sections were washed in water several times (Algan, 1981). Semi-permanent slides were mounted in glycerin or permanent slides were covered with glycerin-gelatin (Vardar, 1987).

\footnotetext{
${ }^{1}$ Artvin Çoruh Üniversitesi, Orman Fakültesi, Orman Mühendisliği, Orman Botaniği Anabilim Dalı, Seyitler Yerleşkesi, 08000 Artvin, Turkey. Corresponding author. Email: oeminagaoglu@artvin.edu.tr
} 
Well stained sections were examined under a light microscope and photographed using an Olympus BX-53 microscope with digital camera attachment DP-73.

\section{Micromorphological analysis}

Micromorphological features of the fruits were studied using a stereomicroscope (Leica M60 with a digital camera attachment DFC 295) and a scanning electron microscope (Zeiss Evo LS 10, ACU-Biltekmer). For scanning electron microscopy, fruits and seed covered with endocarp were separately placed on stubs using double-sided adhesive tape, and coated with gold in a Cressington sputter coater 108 auto coating apparatus for 2 min. Fruits and endocarp were examined and photographed from the same region (from the middle part of the lateral region).

\section{Chromosome count}

For mitotic chromosome observation, root tips were cut off and pretreated with 1Bromonaphtalen at $4{ }^{\circ} \mathrm{C}$ for $16 \mathrm{~h}$ (Ozcan et al., 2011), then fixed in fresh Carnoy absolute alcoholglacial acetic acid $(3: 1)$ for $24 \mathrm{~h}$ at $4^{\circ} \mathrm{C}$. For chromosome counts, root tips were hydrolyzed in $5 \mathrm{~N}$ $\mathrm{HCl}$ for 3-5 min at room temperature and then rinsed with distilled water for 2-3 min. Staining was carried out in lacto-propionic orcein at least for $3 \mathrm{~h}$ at room temperature. Permanent slides were prepared from at least ten well-spread cells. The best metaphase plates were photographed with Olympus BX-53 microscope with digital camera attachment DP-73.

\section{Results and Discussion}

Rhus chinensis Mill. Gard. Dict. ed. 8, n. 7 (1768). R. osbeckii Carrière, Rev. Hort. [Paris]: 111 (1887); R. osbeckii Steud. Nomencl. Bot. [Steudel], ed. 2, 2: 452 (1841); R. semialata Murray, Commentat. Soc. Regiae Sci. Gott. 6: 27, t 3 (1784); Schinus indicus Burm. f., Fl. Ind.: 215 (err. typ. 315) (1768).

(Fig. 1).

Shrub to small deciduous tree, 2-10 m tall; branchlets ferruginous pubescent, lenticellate. Leaves sessile, imparipinnately compound; rachis broadly winged, ferruginous pubescent; leaflets 9-13, leaflet blade ovate to oblong, 7-13×3-7 cm, increasing in size towards apex, adaxially darkgreen, sparsely pubescent or glabrescent, abaxially pale-green, glaucous, and ferruginous pubescent, base rounded to cuneate in terminal leaflet, margin dentate, often crenate, apex acute, lateral veins and reticulate venation impressed adaxially and prominent abaxially; petiole 4-9 $\mathrm{cm}$ long, densely pubescent. Flowers dioecious; inflorescence panicle, densely ferruginous pubescent. Staminate flowers $35-40 \mathrm{~mm}$ long, pedicel short, c. $1 \mathrm{~mm}$, minutely pubescent; calyx pubescent, lobes ovate, c. $1 \mathrm{~mm}$ long, margin ciliate; corolla obovate-oblong, white, c. $2 \mathrm{~mm}$ long; filaments c. $2 \mathrm{~mm}$ long; anthers ovoid, c. $0.7 \mathrm{~mm}$; disk annular, yellow; ovary very reduced or absent. Pistilate flowers: corolla elliptic-ovate, white, c. 1.6-2.0 mm long; calyx lobes c. $0.6 \mathrm{~mm}$ long; staminodes 4 or 5 , disk annular, yellow; ovary ovoid, c. $1 \mathrm{~mm}$ long, densely white pubescent; styles 3; stigma capitate. Drupe globose, slightly compressed, 4-5 mm in diam., mixed pilose and glandular-pubescent, red at maturity.

Flowering period: June to August; fruiting period: September to November.

Specimens examined: A8 Artvin, Hopa, Kemalpaşa, damp roadside, grassland, 15m, 27 July 2013, 41 $30^{\circ} 33^{\prime \prime} \mathrm{N}, 41^{\circ} 32^{\prime} 15^{\prime \prime} \mathrm{E}, \ddot{O}$. Emin. 18677 (ARTH 5250); Artvin, Hopa, Kemalpaşa, 36m,

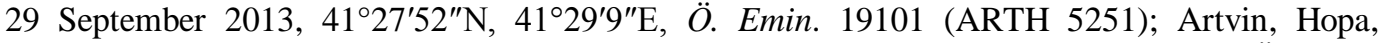
Kemalpaşa, damp roadside, grassland, 10m, 8 May $2014,41^{\circ} 28^{\prime} 22^{\prime \prime} \mathrm{N}, 41^{\circ} 30^{\prime} 17^{\prime \prime} \mathrm{E}, \ddot{O}$. Emin. 19364 (ARTH 5269); Artvin, Arhavi, roadside, 40m, 5 June 2017, 41 ${ }^{\circ} 20^{\prime} 47^{\prime \prime} \mathrm{N}, 41^{\circ} 16^{\prime} 44^{\prime \prime} \mathrm{E}, \ddot{O}$. Emin. 22360 (ARTH 11342). 


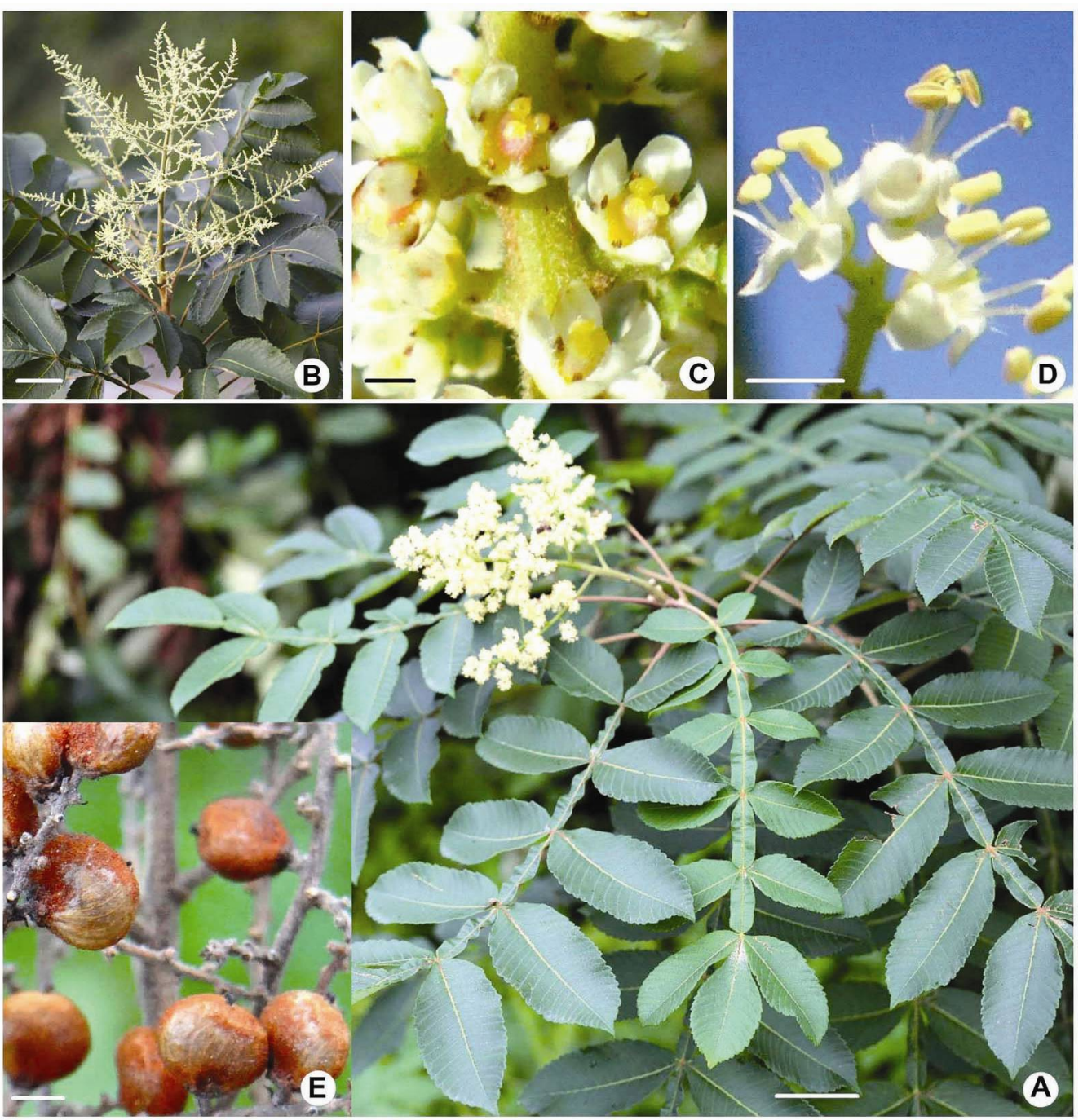

Fig. 1. Rhus chinensis Mill.: A. Winged rachis with pinnate leaves; B. Flowering branch; C. Pistillate flowers; D. Staminate flowers; E. Fruits. Scale bars: A=3 cm, B=5 mm, C=2 mm, D=8 mm, E=2 mm.

Distribution: China, Manchuria, India, Thailand, Korea, Japan, Tibet, Taiwan, North Korea, South Korea, Malaysia, India, Bhutan, Myanmar, Pakistan, Jammu and Kashmir, Laos, Thailand and Cambodia (Hassler, 2017). New record for Turkey.

Ecology: $R$. chinensis grows on damp, humid and gravelly soil including roadsides and forest sides at 20-100 m with Carex pendula Huds., Corylus avellana L., Equisetum fluviatile L., Hypericum xylosteifolium (Spach.) N. Robson, Juncus effusus L., Plantago major L., Polygonum aviculare L, Oxalis corniculata L., Sambucus nigra L. and Sisyrinchium angustifolium Mill.

Uses: Different parts of $R$. chinensis including root, bark, stem, leaf, flowers, fruit, seed and gall are used in the treatment of hemoptysis, inflammations, cough, dysentery, fever, jaundice, malaria, rheumatism, laryngitis, snakebite, stomach-ache and traumatic fractures. Galls on the 
plant are also used for treatment of diarrhoea, hemorrhage, ulcer of mouth, diabetes, and rectal and intestinal cancer (Djakpo and Yao, 2010).

\section{Leaf anatomical characteristics}

Midrib: It is semi-circle and covers a large area. Under the upper and lower epidermis, several layers of collenchyma cells are observed. 12-15 collateral vascular bundles arranged in a circle. The larger bundles present near to upper epidermis are thin walled parenchymatous cells filled in the pith. At least one large resin duct is present in each vascular bundle. Sclerenchymatous sheath can be visible in phloem of vascular bundle as a cap (Fig. 2).

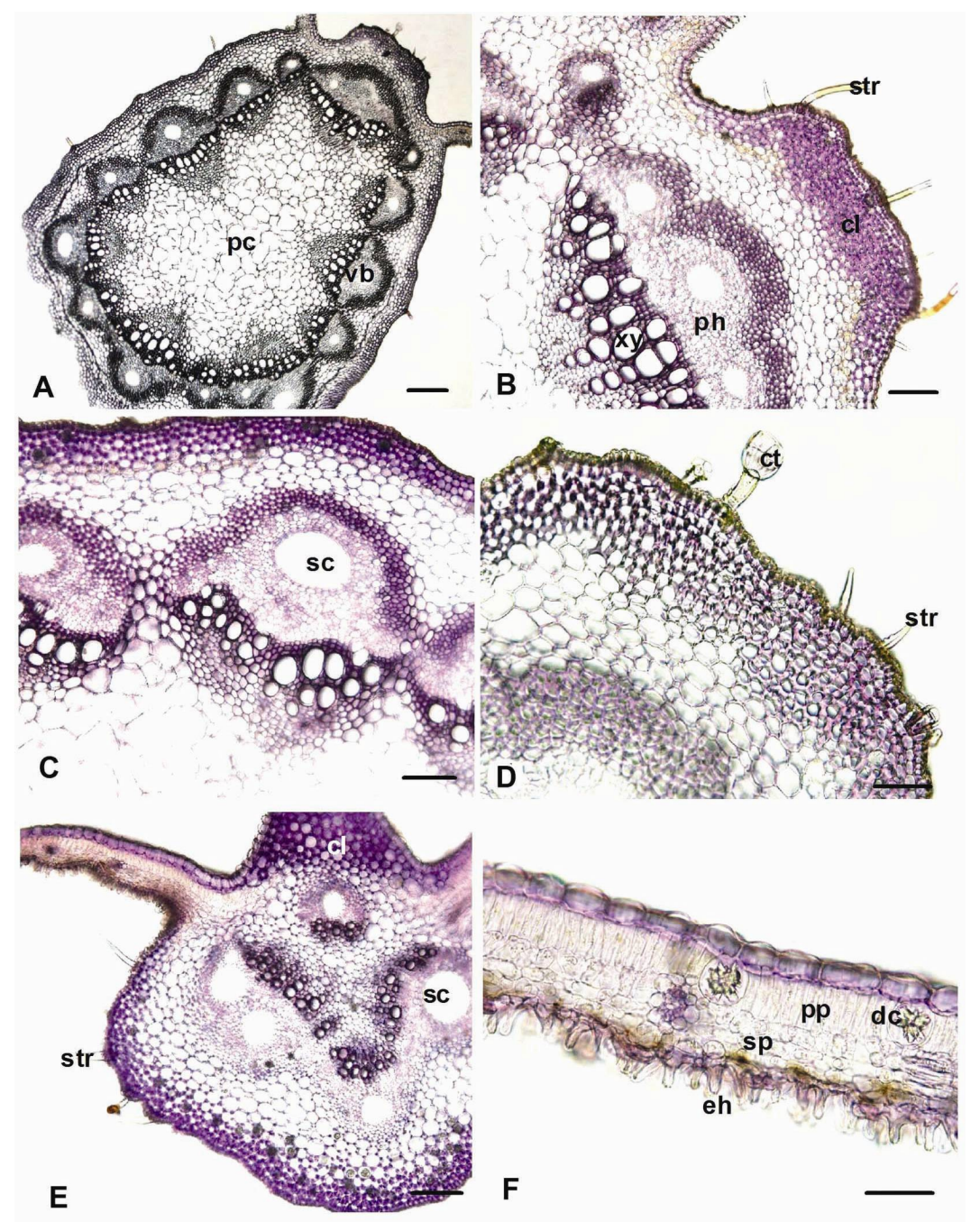

Fig. 2. Leaf anatomy of Rhus chinensis: A-B. Midrib; C. Vascular bundles; D. Trichomes; E. Veinlet; F. Lamina. cl: collenchyma, ct: capitate trichome, eh: epicuticular hair, pc: pith cell, ph: phloem, pp: palisade parenchyma, sc: secretory canal (duct), dc: druse crystals, sp: spongy parenchyma, str: simple trichome, xy: xylem, Scale bars: A $=200 \mu \mathrm{m} ; \mathrm{B}, \mathrm{C}, \mathrm{E}=100 \mu \mathrm{m} ; \mathrm{D}, \mathrm{F}=50 \mu \mathrm{m}$. 
Lamina: The leaves show dorsiventral mesophyll. It is composed of single palisade layer and 3-4 spongy layers. The palisade tissue covers in equal areas to spongy parenchyma. Epidermis is covered with a thick cuticle. Upper epidermal cells with straight walls are distinctly larger than the lower ones (Fig. 2F). Non-glandular and capitate glandular trichomes are sparsely observed in the adaxial surface, but abaxial one included densely non-glandular multicellular and capitate trichomes with 4-8 head cells and epicuticle hairs. It bears hypostomatic type stomata which are found only in abaxial side of leaf (Fig. 3). They are sunken in lower epidermis (Fig. 2C, D).

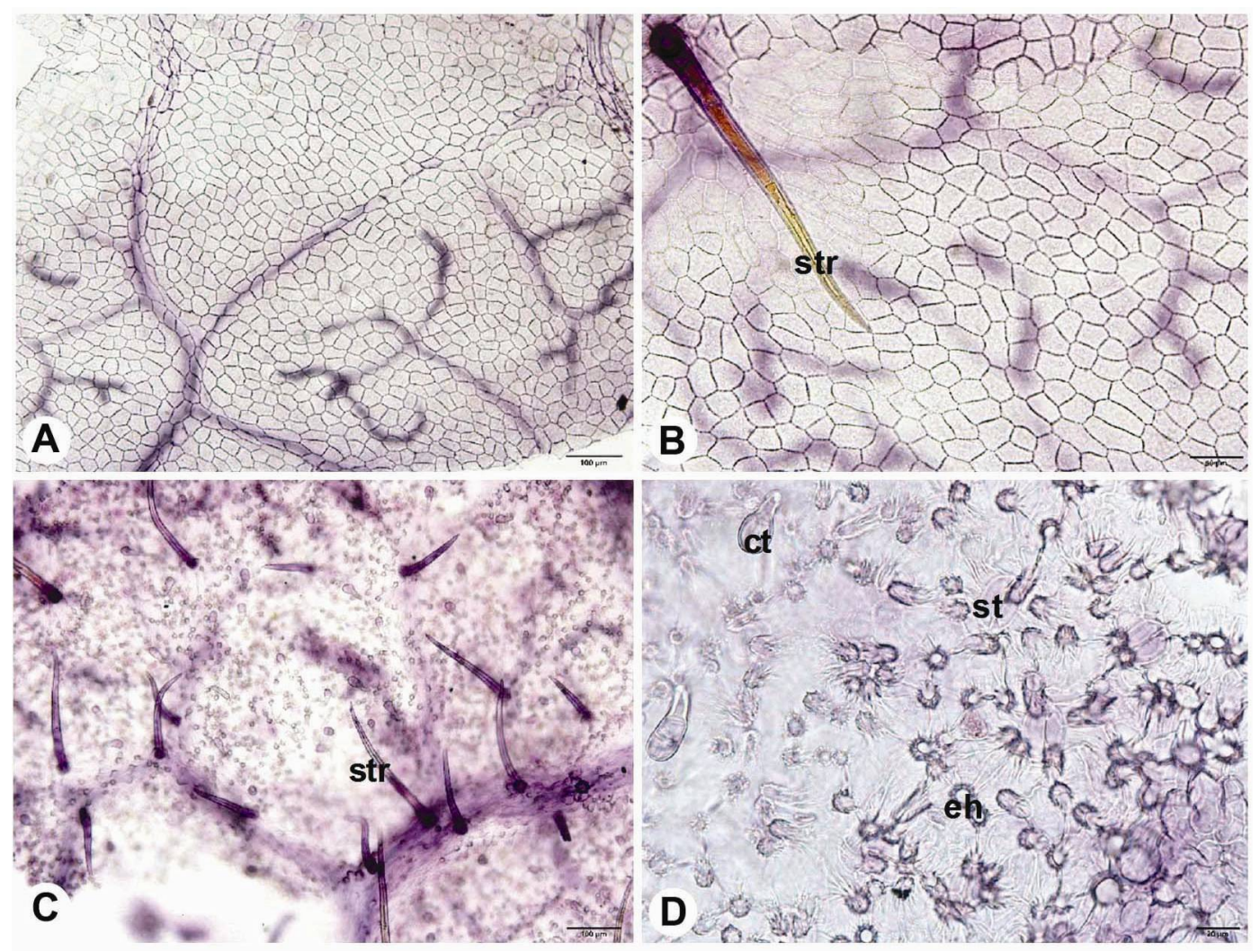

Fig. 3. Paradermal section of leaf. A,B. Adaxial epidermis; C,D. Abaxial epidemis. eh: epicuticular hair; st: stomata; str: simple trichome. Scale bars: A,C. $=100 \mu \mathrm{m} ; \mathrm{B}, \mathrm{D} .=50 \mu \mathrm{m}$.

Crystals: Druse crystal compounds are present in some collenchymatous cells of midrib and inside of the palisade cells of lamina. They are much bigger (Fig. 2F)

$R$. chinensis has dorsiventral mesophyll with single layer of palisade cells and 3-4 layers of spongy cells. Yanping et al. (2001) investigated formation of gall in this species and showed the differences in the ratio of palisade tissue and spongy tissue. In the present study, we observed three types of trichomes in the leaf of $R$. chinensis (Fig. 3). Mobius (1899), and Rost and Gilg (1912) reported two different types of trichomes (thick-walled bristle hairs and club-shaped trichomes) in $R$. vernicifera $\mathrm{L}$. and $R$. toxicodendron L., respectively. Liu et al. (2008) found epicuticular hairs in $R$. chinensis. In the present study, crystal compounds were observed in $R$. chinensis (Fig. 2). McNair (1921) reported these types of crystals in $R$. diversiloba Torr. \& A. Gray [Toxicodendron diversilobum (Torr. \& A.Gray) Greene]. McNair (l.c.) also reported resin 
ducts in $R$. diversiloba. Harada (1932) reported resin ducts in the petiole and veinlets of $R$. succedanea $\mathrm{L}$. In the present study similar results were found for $R$. chinensis as like in $R$. diversiloba. Therefore our results are in accordance with previous studies.

\section{Fruit micromorphology}

Fleshy fruit has reddish colour with round shape, and endocarp is laterally compressed. Fruit length ranged from 4.5 to $4.7 \mathrm{~mm}$. Results of fruit micromorphology are shown in Fig. 4. Exocarp cells are undulate and more or less inflated with striate surface. Epidermal surface was covered with glandular trichomes. Endocarp has regular sclerified cells.
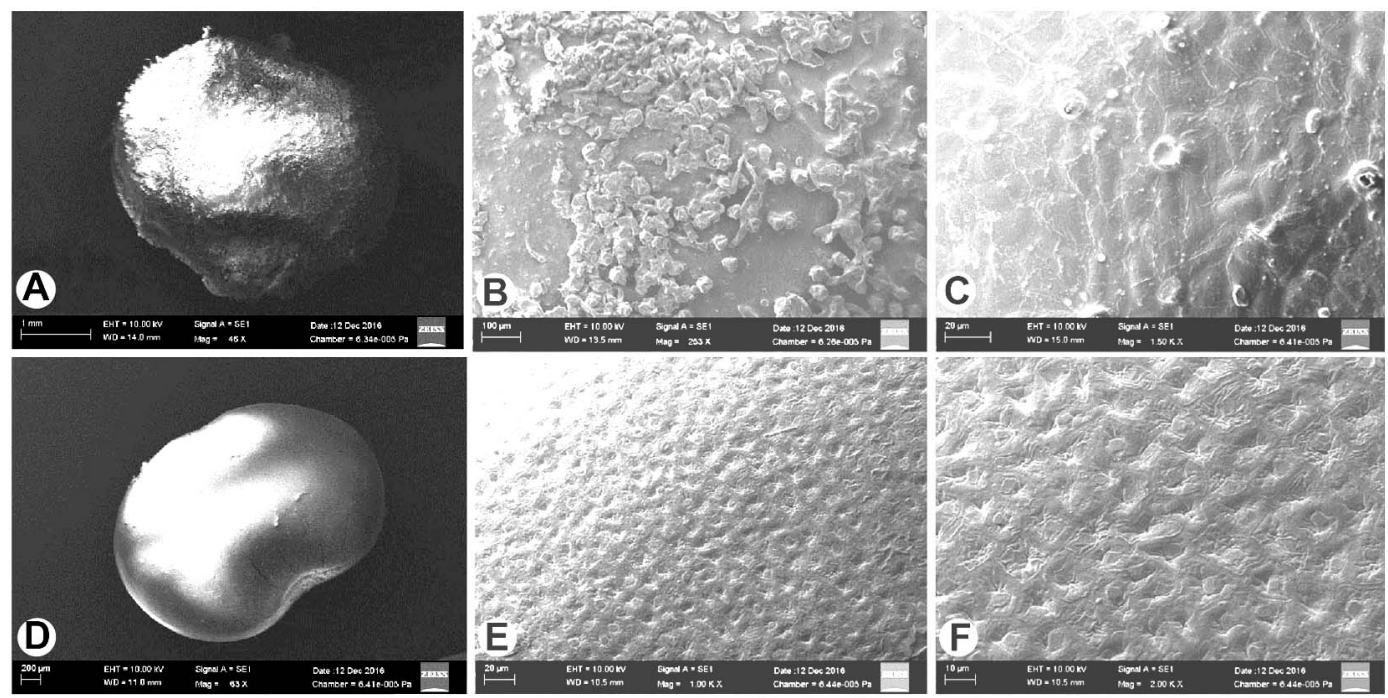

Fig. 4. SEM micrography of fruit of Rhus chinensis. A-C. Fruit; D-F. Endocarp.

\section{Chromosome number}

Somatic chromosome number of $R$. chinensis has been determined as $2 n=2 \mathrm{x}=30+0-2 \mathrm{~B}$ (Fig.5).

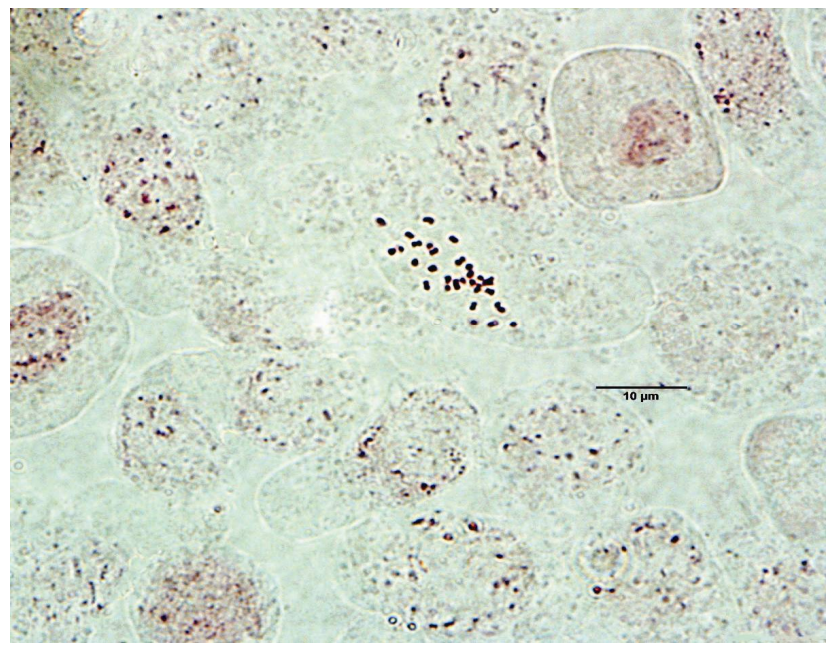

Fig. 5. Somatic metaphase of Rhus chinensis. 
Two B chromosome have also been found. In a previous report, Shang et al. (1990) documented chromosomes of four Rhus species, and reported chromosome number of R. chinensis as $2 n=30$ $+0-5 \mathrm{~B}$ and chromosome numbers of other three taxa as $2 n=30$. However, triploid cultivar was also detected in their study for $R$. verniciflua as $2 n=3 \mathrm{x}=45$. Parfitt et al. (1990) found gametic chromosome number of $R$. aromatica Aiton var. pilosissima (Engl.) Shinners as $n=15$. Our results are in accordance with those previous reports and only diploid number was observed for $R$. chinensis in this study.

\section{Acknowledgements}

The authors are thankful to the Ziraat Bank in Turkey for their financial supports.

\section{References}

Algan, G. 1981. Bitkisel Dokular İçin Mikroteknik, İstanbul. Frrat University Science Faculty Press (in Turkish), $94 \mathrm{pp}$.

Barkley, F.A. 1937. A monographic study of Rhus and its immediate allies in North and Central America, including the West Indies. Ann. Miss. Bot. Gard. 24: 265-498.

Davis, P.H. (Ed.). 1988. Flora of Turkey and the East Aegean Islands. Vol. 10. Edinburgh University Press, Edinburgh, $590 \mathrm{pp}$.

Davis, P.H., Coode, M.J.E. and Cullen, J. 1967. Rhus L. In: Davis, P.H. (Ed.), Flora of Turkey and the East Aegean Islands, Vol. 2. Edinburgh University Press, Edinburgh, pp. 543-544.

Djakpo, O. and Yao, W. 2010. Rhus chinensis and Galla chinensis folklore to modern evidence: review. Phytother. Res. 24: 1739-1747.

Eminağaoğlu, Ö. (Ed.) 2015. Artvin'in Doğal Bitkileri (Native Plants of Artvin). Promat Press, Istanbul, $456 \mathrm{pp}$.

Eminağaoğlu, Ö, Kutbay, H.G., Özkan, Z.C. and Ergül, A. 2008. Flora of the Camili Biosphere Reserve Area (Borçka, Artvin, Turkey). Turk. J. Bot. 32: 43-90.

Eminağaoğlu, Ö. and Anşin, R. 2003. The flora of Hatila Valley National Park and its close environs (Artvin). Turk. J. Bot. 27: 1-27.

Eminağaoğlu, Ö. and Anşin, R. 2004. Flora of the Karagol-Sahara National Park (Artvin) and its environs. Turk. J. Bot. 28: 557-590.

Eminağaoğlu, Ö. and Ozcan, M. 2013. Euonymus leiophloeus (Celastraceae) - A new record for the flora of Turkey. Bangladesh J. Plant Taxon. 20(2): 263-266.

Eminağaoğlu, Ö. and Ozcan, M. 2014. Systematics of Sisyrinchium angustifolium Mill. (Iridaceae), a newly recorded species from Turkey. Bangladesh J. Plant Taxon. 21(2): 175-180.

Güner, A., Özhatay, N., Ekim, T. and Başer, K.H.C. (Eds). 2000. Flora of Turkey and the East Aegean Islands. Vol. 11. Edinburgh University Press, Edinburgh, 680 pp.

Harada, M. 1932. Anatomical study on the leaves of Rhus succedanea, especially on the distribution of the resin canal. J. Soc. Forestry 14(4): 238-250.

Hassler, M. 2017. World Plants: Synonymic Checklists of the Vascular Plants of the World. In: Roskov, Y., Abucay, L., Orrell, T., Nicolson, D., Bailly, N., Kirk, P.M., Bourgoin, T., DeWalt, R.E., Decock, W., De Wever, A., Nieukerken, E. van Zarucchi, J. and Penev, L. (Eds), Species 2000 and ITIS Catalogue of Life. Naturalis, Leiden.www.catalogueoflife.org [Accessed on 7 June 2017].

Hsu, T.W. and Su, M.H. 2013. A taxonomic revision of Rhus chinensis Mill. (Anacardiaceae) in Taiwan. Taiwan J. For. Sci. 28(3): 145-151.

IUCN 2017. The IUCN Red List of Threatened Species. Version 2017-1. http://www.iucnredlist.org. [Accessed on 07 June 2017].

Linchevskii, I.A. 1974. Rhus L. In: Komarov, V.L. (Ed.), Flora of the U.S.S.R, Vol. 14, Jerusalem, Israel Program for Scientific Translation, pp. 530-531. 
Liu, Y., Zhao, M., Li, Z. and Jiang, J. 2008. Adaptation of Rhus chinensis to drought stress in Karst area: Insights from anatomical structure of leaf. Carsologica Sinica 27(3): 235-239.

McNair, J.B. 1921. A study of Rhus diversiloba with special reference to its toxicity. Am. J. Bot. 8: 127-146.

Mobius, M.A. 1899. Der Japanische Lackbaum. Abhandl. Senckenberg. Naturforsch. Ges. 20: 201-247.

Ozcan, M., Hayırlığlu-Ayaz, S. and Inceer, H. 2011. Chromosome reports in some Cirsium (Asteraceae, Cardueae) taxa from north-east Anatolia. Caryologia 64(1): 55-66.

Özhatay, F.N., Kültür, Ş. and Gürdal, M.B. 2011. Checklist of additional taxa to the supplement Flora of Turkey V. Turk. J. Bot. 35: 589-624.

Parfitt, B.D., Pinkava, D.J., Rickel, D., Fillipi, D., Eggers, B. and Keil. D.J. 1990. Documented chromosome numbers 1990: 1. Miscellaneous North American vascular plants. Sida 14: 305-308.

Rost, E. and Gilg, E. 1912. Der Giftsumach, Rhus toxicodendron L., und seine Giftwirkungen. Ber Deutsch. Pharm. Ges. 22: 296-358.

Shang, Z.Y., Zhang, J.Z., Li, R.J. and Liu, Q.H. 1990. The chromosome observation on four species in the genus Rhus. J. Wuhan Bot. Res. 8: 13-17.

Vardar, Y. 1987. Botanikte Preparasyon Teknigi. Izmir, Ege University Science Faculty Press (in Turkish), pp. 1-66.

Yanping, Z., Xingfeng, Z., Lizhen, Y. and Juan, L. 2001. A study on anatomical structure of horned gall and the leaf of Rhus chinensis. J. Nanjing Forestry Univ. (Natural Science Edition) 25(6): 6-10.

Yi, T., Miller, A.J. and Wen, J. 2007. Phylogeny of Rhus (Anacardiaceae) based on sequences of nuclear Niai3 intron and chloroplast trnC-trnD. Syst. Bot. 32(2): 379-391.

Yuksel, E. and Eminağaoğlu, Ö. 2017. Flora of the Kamilet Valley (Arhavi, Artvin, Turkey). Int. J. Ecosyst. Ecol. Sci. 7(4): 905-914.

(Manuscript received on 8 June 2017; revised on 23 March 2018) 